\title{
Use of loop and clips to prevent migration of esophageal stent
}

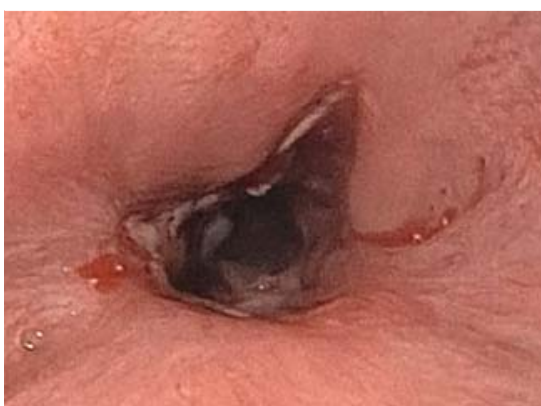

- Fig. 1 Esophageal stricture with ulcerated surrounding mucosa.

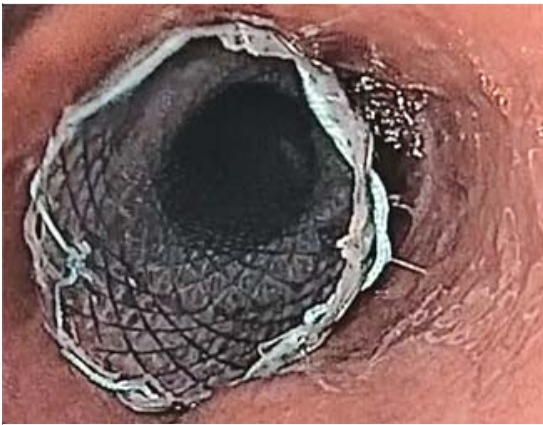

Fig. 2 Self-expandable metal stent deployed at the stricture site.

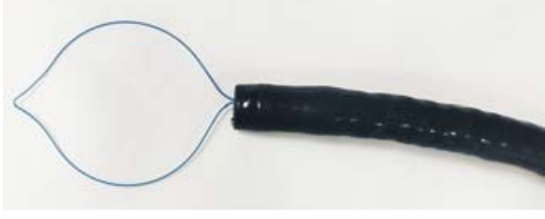

- Fig. 3 Endoloop pulled inside the endoscope channel.

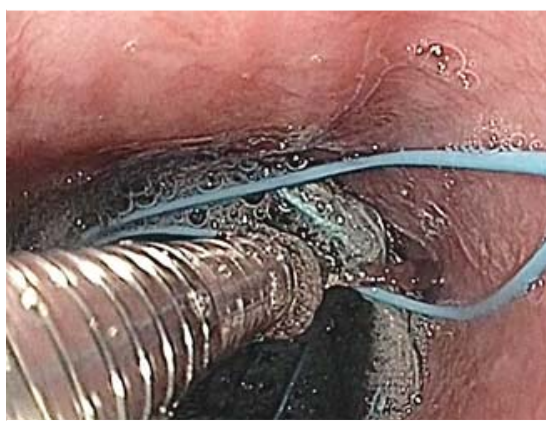

Fig. 4 Fixation of the loop to the upper part of the stent with the help of throughthe-scope clips.

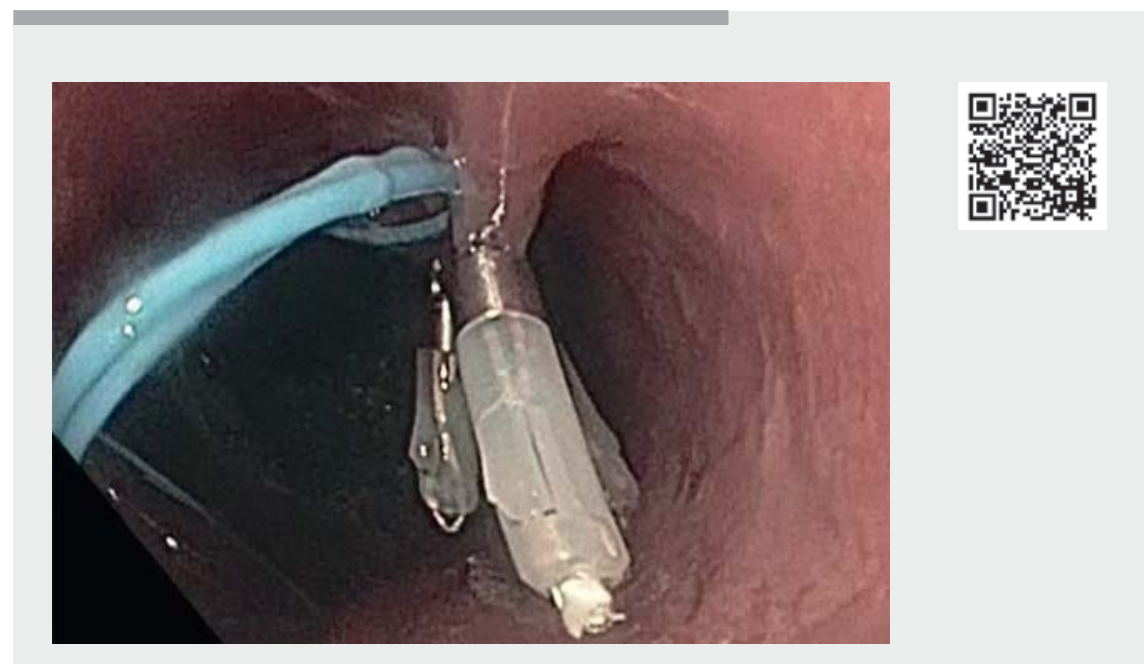

Video 1 Application of endoloop and clips to fix a self-expandable metal stent to the esophageal wall in order to prevent migration.

A 25-year-old gentleman presented with dysphagia for solids and liquids. He had a history of accidental ingestion of hightemperature melted iron particles 4 weeks back while working in the iron industry. Upper gastrointestinal endoscopy revealed a stricture with ulceration in the lower esophagus at $35 \mathrm{~cm}$ from the incisors ( $\vee$ Fig. 1 ). The 9.8-mm diameter endoscope could not be negotiated beyond the stricture site; further examination with a 5.5-mm-diameter endoscope revealed a stricture length of $3 \mathrm{~cm}$ and normal gastric mucosa. The patient underwent four sessions of dilatation with Savary-Gilliard dilators up to $15 \mathrm{~mm}$, but the stricture persisted. A fully covered esophageal self-expandable metal stent ( $18 \times 100 \mathrm{~mm}$; Wallflex, Boston Scientific) was deployed as a rescue treatment ( $\triangleright$ Fig. 2). In view of the risk of migration, the stent was fixed to the esophageal wall with the help of an endoloop and clips ( $\vee$ Video 1). A 30-mm endoloop (model no. MAJ-254; Olympus) was grasped with a forceps and partially pulled inside the channel ( $\triangleright$ Fig. 3). The endoloop was released near the upper margin of the stent. One end of the loop was fixed with the help of through-the-scope clips (HX610-090 L, Olympus) to the upper part of the stent ( $\vee$ Fig.4). Six clips were applied to fix the endoloop to the esophageal wall.

Fully covered metal stents are effective treatment for benign esophageal disease, but migration of the stent remains an important issue [1]. Various techniques have been used to prevent the migration of an esophageal stent. Overthe-scope clips [2], Shim technique [3], a suturing device [4], and a mucosal flap technique [5] have all been used to fix the stent. We have described a new technique using the widely available endoloop and through-the-scope clips.

Endoscopy_UCTN_Code_TTT_1AO_2AZ

\section{Acknowledgments}

We acknowledge the role of Ashu and Rohit in collecting the images and editing the video for this publication. 


\section{Competing interests}

The authors declare that they have no conflict of interest.

The authors

Vikas Singla ${ }^{\circledR}$, Shivam Khare, Anil Arora, Ashish Kumar, Praveen Sharma, Naresh Bansal, Shrihari Anil Anikhindi ${ }^{\circ}$

Institute of Liver, Gastroenterology and Pancreaticobiliary Sciences, Sir Ganga Ram Hospital, New Delhi, India

Corresponding author

\section{Vikas Singla, MD}

Institute of Liver, Gastroenterology and Pancreaticobiliary Sciences, Sir Ganga Ram Hospital, Rajinder Nagar, New Delhi, India 110060

Fax: + 91-11-25861002

singlavikas1979@gmail.com

\section{References}

[1] Thomas T, Abrams KR, Subramanian $V$ et al Esophageal stents for benign refractory strictures: a meta-analysis. Endoscopy 2011; 43: 386-393

[2] Watanabe K, Hikichi T, Nakamura J et al. Feasibility of esophageal stent fixation with an over-the-scope-clip for malignant esophageal strictures to prevent migration. Endosc Int Open 2017; 5: E1044-E1049

[3] Shim CS, Cho YD, Moon JH et al. Fixation of a modified covered esophageal stent: its clinical usefulness for preventing stent migration. Endoscopy 2001; 33: 843-848

[4] Kantsevoy SV, Bitner M. Esophageal stent fixation with endoscopic suturing device. Gastrointest Endosc 2012; 76: 1251-1255

[5] Singla V, Arora A, Khare S et al. A novel technique to prevent migration of esophageal stent. Endoscopy 2020; 52: 1040-1041

\section{Bibliography}

Endoscopy 2021; 53: E421-E422

DOI 10.1055/a-1326-1143

ISSN 0013-726X

published online 27.1.2021

(c) 2021. Thieme. All rights reserved.

Georg Thieme Verlag KG, Rüdigerstraße 14,

70469 Stuttgart, Germany

\section{ENDOSCOPY E-VIDEOS \\ https://eref.thieme.de/e-videos} 回回 Endoscopy E-Videos is a free

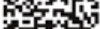
on interesting cases and new

techniques in gastroenterological endoscopy. All papers include a high quality video and all contributions are freely accessible online.

This section has its own submission website at https://mc.manuscriptcentral.com/e-videos 